\title{
Low Atmospheric Nitrogen Loads Lead to Grass Encroachment in Coastal Dunes, but Only on Acid Soils
}

\author{
Eva Remke, ${ }^{1,4 *}$ Emiel Brouwer, ${ }^{2}$ Annemieke Kooijman, ${ }^{3}$ Irmgard Blindow, ${ }^{1}$ \\ and Jan G. M. Roelofs ${ }^{5}$
}

\begin{abstract}
${ }^{1}$ Biological Station of Hiddensee, Ernst-Moritz-Arndt-University Greifswald, Biologenweg 15, 18565 Kloster, Germany; ${ }^{2}$ Research Center B-WARE B.V., Radboud University Nijmegen, Heyendaalseweg 135, 6525 AJ Nijmegen, The Netherlands; ${ }^{3}$ Institute of Biodiversity and Ecosystem Dynamics, Physical Geography, University of Amsterdam, Nieuwe Achtergracht 166, 1018 WV Amsterdam, The Netherlands; ${ }^{4}$ Bargerveen Foundation, Department of Animal Ecology, Radboud University Nijmegen, Toernooiveld 1, 6525 ED

Nijmegen, The Netherlands; ${ }^{5}$ Department of Aquatic Ecology and Environmental Biology, Radboud University Nijmegen, Heyendaalseweg 135, 6525 AJ Nijmegen, The Netherlands
\end{abstract}

\begin{abstract}
The impact of atmospheric $\mathrm{N}$-deposition on succession from open sand to dry, lichen-rich, short grassland, and tall grass vegetation dominated by Carex arenaria was surveyed in 19 coastal dune sites along the Baltic Sea. Coastal dunes with acid or slightly calcareous sand reacted differently to atmospheric wet deposition of $5-8 \mathrm{~kg} \mathrm{~N} \mathrm{ha}^{-1} \mathrm{y}^{-1}$. Accelerated acidification, as well as increased growth of Carex and accumulation of organic matter, was observed only at acid sites with $\mathrm{pH}_{\mathrm{NaCl}}$ of the parent material below 6.0. At sites with slightly calcareous parent material, increased $\mathrm{N}$-deposition had no effect. A trigger for grass encroachment seems to be high acidification in early successional stages to below $\mathrm{pH}_{\mathrm{NaCl}}$ 4.0. Metals like $\mathrm{Al}$ or $\mathrm{Fe}$ become freely available and may hamper intolerant species. At acid sites, N-mineralization increases
\end{abstract}

with elevated N-deposition, which may further stimulate Carex arenaria. Due to high growth plasticity, efficient resource allocation and tolerance of high metal concentrations, $C$. arenaria is a superior competitor under these conditions and can start to dominate the dune system. Carex-dominated vegetation is species-poor. Even at the moderate Nloads in this study, foliose lichens, forbs and grasses were reduced in short grass vegetation at acid sites. Species indicating these first effects of atmospheric deposition on dry, lichen-rich, short grasslands are identified and recommendations for restoration of grass-encroached sites given.

Key words: Carex arenaria; nitrogen deposition; species loss; Baltic Sea; acidification; organic matter.
Received 16 April 2009; accepted 10 August 2009; published online 23 October 2009

*Corresponding author; e-mail: remke@science.ru.nl

\section{INTRODUCTION}

Effects of atmospheric nitrogen deposition on seminatural ecosystems have been intensively studied in the last three decades. Nutrient-poor and weakly buffered ecosystems are particularly vulnerable. In dry ecosystems in north-western and central 
Europe, negative impacts of high atmospheric deposition (15-30 kg N ha-1 $\mathrm{y}^{-1}$ ) have been described for forests (Houdijk and others 1993; van Dijk and others 1989, 1990), heathlands (Bobbink and others 1992; Power and others 1998; Roelofs 1986; van den Berg and others 2005) and some types of coastal dunes (Jones and others 2004; Kooijman and others 1998). However, even low levels of atmospheric deposition may have negative effects. For coastal dunes of the Baltic Sea, which only receive $3-8 \mathrm{~kg} \mathrm{~N} \mathrm{ha}^{-1} \mathrm{y}^{-1}$, critical loads for dry, acid, lichen-rich grasslands as low as 4$6 \mathrm{~kg} \mathrm{~N} \mathrm{ha}^{-1} \mathrm{y}^{-1}$ have been suggested (Remke and others 2009).

Increased atmospheric $\mathrm{N}$-deposition may affect various ecosystem patterns and processes. Elevated $\mathrm{N}$-loads not only stimulate eutrophication and plant growth, but also lead to acidification and loss of buffer capacity, increasing the availability of toxic metals $\left(\mathrm{Al}^{3+}\right.$ and $\mathrm{Fe}^{3+}$ ) within the soil (Aerts and Bobbink 1999; Heij and Schneider 1991). Al and Fe concentrations of 50-100 ppm in plant tissue can harm acid intolerant species and disturb the Pmetabolism (Fink 2007). Higher soil Al/Ca-ratios are assumed to be toxic for plants growing at intermediate $\mathrm{pH}$ levels (de Graaf and others 1997) as $\mathrm{Ca}^{2+}$ inhibits the uptake of $\mathrm{Al}^{3+}$ (Marschner 1995).

High N-deposition may also accelerate succession rates in acid grasslands, heathlands and dune pools (Bobbink and others 1998; Achermann and Bobbink 2003). Vegetation becomes dominated by tall graminoids like Deschampsia flexuosa (L.) Trin., Molinia caerulea (L.) Moench, Carex arenaria L. and Calamagrostis epigejos (L.) Roth (Bobbink and others 1998; Kooijman and others 1998; Remke and others 2009). Processes behind this species change are a switch from competition for nutrients to a competition for light and space, and resistance of plant species to toxicity such as high metal concentrations or a very low $\mathrm{pH}$ (Bobbink and others 1998; de Graaf and others 1997; Kleijn and others 2008). In the Baltic region, dry, lichen-rich dune grasslands are reduced as $\mathrm{N}$-affected dunes become dominated by Carex arenaria (Remke and others 2009). Under unpolluted conditions, the succession pathway starts with bare sand, which is then slowly colonized by a few pioneer graminoids like Corynephorus canescens P. Beauv. and Carex arenaria, by lichens like Cetraria muricata (Ach.) Eckfeldt and mosses like Ceratodon purpureus (Hedw.) Brid. With time, the bare soil is totally covered by low, but highly characteristic vegetation. These short grasslands contain about 20-25 plant species (per relevee of $16-25 \mathrm{~m}^{2}$ ), mostly lichens and mosses (Ellenberg 1996). Grey dunes and wet dune slacks add an essential part to the species diversity of coastal dunes and habitats. Species diversity of coastal habitats comprises $40-70 \%$ of the total diversity in Flanderen and The Netherlands (Kooijman 2004; Provoost and Bonte 2004), about 25\% on the West Frisian islands (Niedringhaus and others 2008), and forms therefore an essential part of total biodiversity.

Succession from bare sand to fully developed lichen-rich dune grassland may take 50-70 years, and is accompanied by a moderate decrease in soil $\mathrm{pH}(0.5-1 \mathrm{pH}$ units) and accumulation of organic matter (Ellenberg 1996). Eventually taller graminoids, dwarf shrubs or trees become dominant. The sequence from young short via old to tall grassland is one of the major succession lines for Baltic coastal dunes and has been described for the Vistula Spit (Steffen 1931), the Łeba bar (Hueck 1932) as well as the Curonian spit (Paul 1953). However, with increased levels of atmospheric N-deposition, crucial soil processes may change, and lead to dominances of dense, tall grass stands.

The aim of this study is to determine,(i) which soil processes promote the shift from lichen-rich, short, dry grasslands to a dominance of Carex arenaria, (ii) which process changes can be linked to atmospheric $\mathrm{N}$-deposition, (iii) to specify characteristics of Carex arenaria stands under different atmospheric N-loads, and (iv) to describe the effects of elevated deposition loads on species composition and richness. Finally, early indicators for the influence of low atmospheric N-deposition levels are listed, and recommendations for restoration of dry, coastal dunes dominated by tall graminoids are given.

\section{Field Sites}

The 19 coastal dune sites are spread over a large geographical gradient from the Kattegat in the west of the Southern Baltic to the Baltic proper in the east (Figure 1; Remke and others 2009). The research area therefore stretches from the Atlantic through Central Europe to the Baltic terrestrial ecoregion (Olson and others 2004). The average annual temperature decreases from $8^{\circ} \mathrm{C}$ in Denmark to $5^{\circ} \mathrm{C}$ in Estonia (Table 1) as the climate gets more continental. Another gradient exists for sea water salinity and therefore salt-spray. Salinity decreases steeply within in the Kattegat from 24 to approximately 10 PSU and ranges mainly between 7 and 8 PSU in the Southern Baltic and Baltic proper (Table 1). All 19 sites have parent sand material with $\mathrm{pH}_{\mathrm{NaCl}}$ below 6.5 and receive precipitation of 500-700 $\mathrm{mm} \mathrm{y}^{-1}$ (Table 1). All sites are open dunes 


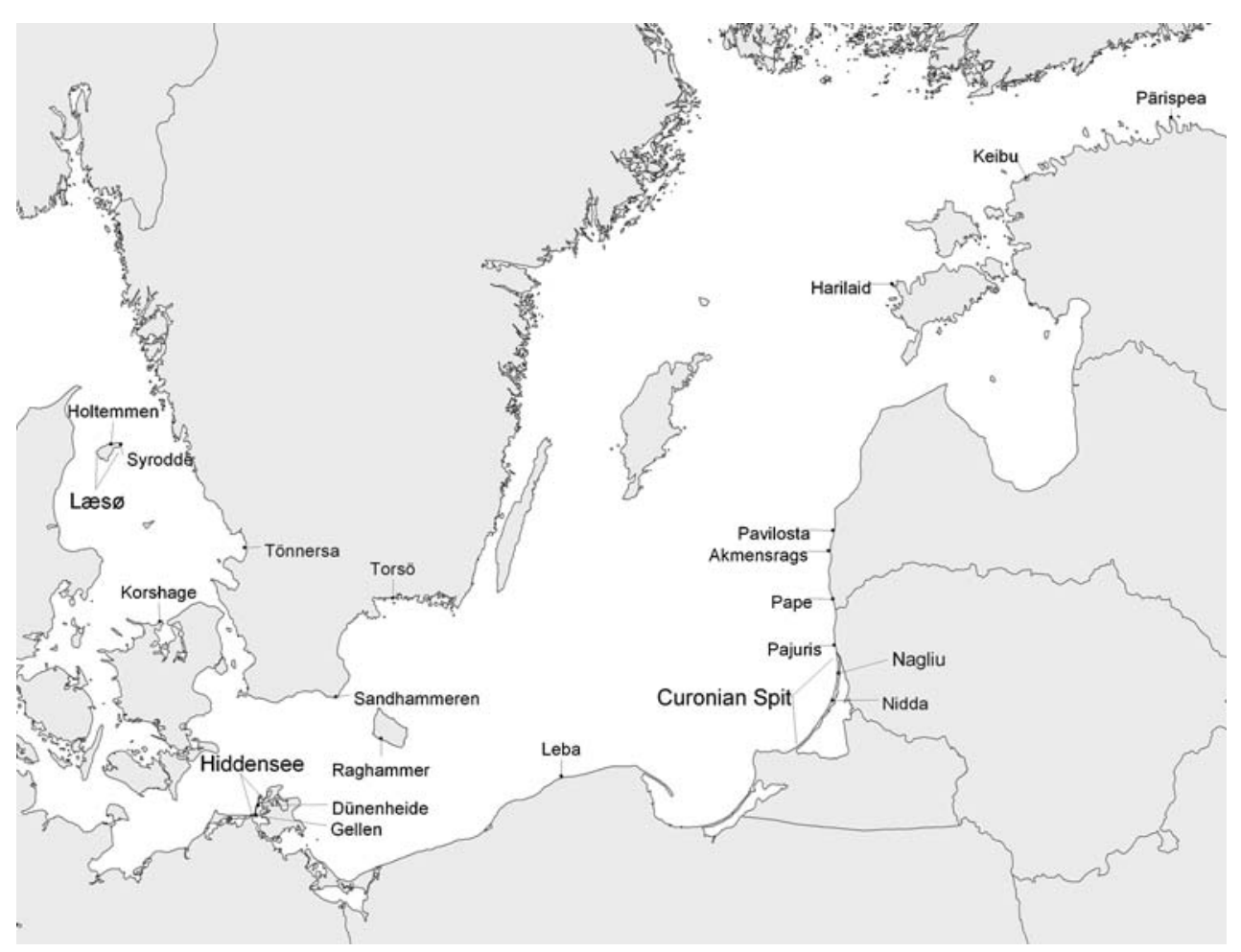

Figure 1. Map of field sites (reprinted from Remke and others 2009, with permission from Elsevier)

Table 1. Field Sites with Synonym, Country, Geographical UTM Coordinates (from Google Earth), Long-Term Annual Mean Values for Temperature and Precipitation, and Sea Water Salinity

\begin{tabular}{|c|c|c|c|c|c|c|}
\hline Name/synonym & Country & $\begin{array}{l}\text { Longitude, } \\
\text { UTM }\end{array}$ & $\begin{array}{l}\text { Latitude, } \\
\text { UTM }\end{array}$ & $\begin{array}{l}\text { Temperature, } \\
{ }^{\circ} \mathrm{C}\end{array}$ & $\begin{array}{l}\text { Precipitation, } \\
\mathrm{mm} \mathrm{y}^{-1}\end{array}$ & $\begin{array}{l}\text { Salinity, } \\
\text { PSU }\end{array}$ \\
\hline Akmensrags $^{1}$ & Latvia & 56411065 & 20989034 & 6.8 & 627 & 7.2 \\
\hline Dünenheide/Hiddensee ${ }^{2}$ & Germany & 54550269 & 13099371 & 8.0 & 564 & 9.0 \\
\hline Gellen/Hiddensee $^{2}$ & Germany & 54479486 & 13064725 & 8.0 & 564 & 9.0 \\
\hline Harilaid $^{2}$ & Estonia & 58489564 & 21843912 & 5.6 & 703 & 6.9 \\
\hline Holtemmen/Laes $\emptyset^{5}$ & Denmark & 57302031 & 10994222 & 7.9 & 576 & 24.0 \\
\hline Keibu $^{4}$ & Estonia & 59241349 & 23739389 & 5.1 & 686 & 7.0 \\
\hline Korshage $^{6}$ & Denmark & 55974190 & 11777358 & 7.3 & 500 & 18.4 \\
\hline Nagliu/Curonian Spit $\mathrm{NP}^{7}$ & Lithuania & 59659837 & 21083870 & 7.8 & 750 & 7.3 \\
\hline Nida/Curonian Spit $\mathrm{NP}^{7}$ & Lithuania & 55284024 & 20958343 & 7.8 & 750 & 7.3 \\
\hline Pajuris $^{8}$ & Lithuania & 55843364 & 21062018 & 7.0 & 735 & 7.3 \\
\hline Pape $^{1}$ & Latvia & 56150317 & 21027620 & 6.8 & 627 & 7.2 \\
\hline Pärispea ${ }^{4}$ & Estonia & 59659837 & 25683665 & 5.1 & 686 & 6.4 \\
\hline Pavilosta $^{1}$ & Latvia & 56893958 & 21191670 & 6.8 & 627 & 7.0 \\
\hline Raghammer/Bornholm 9 & Denmark & 55015227 & 14926422 & 7.7 & 572 & 7.9 \\
\hline Łeba/Slovinski NP ${ }^{10}$ & Poland & 54682510 & 17101320 & 7.7 & 575 & 7.5 \\
\hline Sandhammeren $^{3}$ & Sweden & 55378837 & 14180429 & 7.4 & 600 & 7.7 \\
\hline Syrodde/Laesø $\varnothing^{5}$ & Denmark & 57323485 & 11195125 & 7.9 & 576 & 24.0 \\
\hline Tönnersa ${ }^{3}$ & Sweden & 56555071 & 12947505 & 7.3 & 700 & 18.1 \\
\hline Torsö $^{3}$ & Sweden & 55999030 & 14657380 & 7.4 & 550 & 7.7 \\
\hline
\end{tabular}

$N P=$ national park

Sources for climate data: ${ }^{1}$ www.worldclimate.com, station Liepaja; ${ }^{2}$ www.worldclimate.com, station Greifswald; ${ }^{3}$ temperature: Eggertsson-Karlström (2004); precipitation: Raab and Vedin (1995); ${ }^{4}$ Ratas and Nilson (1997); ${ }^{5}$ Walter and Lieth (1967) in Biermann (1999); ${ }^{6}$ temperature: www.dmi.dk, regions København and Nordsjalland; precipitation: Jensen (1986); ${ }^{7}$ Anonymous (2004); ${ }^{8}$ www.wetter.com, station Kleipeda; ${ }^{9}$ www.worldclimate.com, station Duoedde; ${ }^{10}$ temperature; www.worldclimate.com, station Eeba; precipitation: Walna and others (2003). Salinity values are obtained from the mean grid cell values for the period 1900-2005 (Feistel and others 2008). 
without any physical barrier like a forest towards the sea, and have less than $10 \%$ cover of trees. During the last decade, management impacts such as grazing or burning have not been intensive.

The dataset was separated into two main groups, with $\mathrm{pH}$ of the parent material below ('acid') or above ('slightly calcareous') 6.0 (Table 2), that is, below or within the carbonate buffer range. Above $\mathrm{pH}$ 6.5-6.2, the system is buffered by dissolution of calcium carbonate below $\mathrm{pH} 6.0$ by cation exchange, and below pH 5.0 by aluminium and iron buffer systems (Scheffer and Schachtschabel 1998). In addition, both pH-groups were separated into two $\mathrm{N}$-deposition classes below and above a total wet $\mathrm{N}$-deposition of $5 \mathrm{~kg} \mathrm{~N} \mathrm{ha}^{-1} \mathrm{y}^{-1}$, estimated by $\mathrm{N}$-content of the biomonitor Cladonia portentosa (Remke and others 2009; Table 2). The calculated total wet $\mathrm{N}$-deposition ranged from 2.6 to 7.8 total $\mathrm{N} \mathrm{kg} \mathrm{ha}{ }^{-1} \mathrm{y}^{-1}$, but critical loads were estimated as 4-6 $\mathrm{kg} \mathrm{N} \mathrm{ha}^{-1} \mathrm{y}^{-1}$ (Remke and others 2009). The $\mathrm{N}$-content in C. portentosa proved to be a suitable biomonitor of $\mathrm{N}$-deposition in remote areas as it explained approximately $50 \%$ of the variation in wet $\mathrm{N}$-deposition measured at nearby EMEP stations (regression equation: $C$. portentosa tissue $\mathrm{N}[\%]=$ $0.0228 \times \mathrm{N}$-deposition $\left[\mathrm{kg} \mathrm{ha}^{-1} \mathrm{y}^{-1}\right]+0.3385, R^{2}=$ $0.5223, P=0.008$; further discussion see Remke and others 2009).

\section{Materials AND Methods}

In each of the 19 dune sites, three $2 \times 2 \mathrm{~m}^{2}$ plots were selected in June-July 2005, in a sequence from young short via old short to tall grassland. First, early successional stage is characterized by short, dry grassland, with at least $30 \%$ open sand area, second stage by older and lichen-rich, short grassland, with open sand below 5\%, and third stage is dominated by tall grasses with at least approximately $50 \%$ cover of sand sedge (Carex arenaria). In each plot, species cover was estimated. If necessary, species were dried and identified using a microscope and coloring techniques. For species determination the following literature was used: for vascular plants Rothmaler and others (2002), Oberdorfer (1994) and Hegi and Conert (1998), additionally for Salix spp. Lautenschlager-Fleury and Lautenschlager (1994), for mosses Frahm and Frey (1992) and for lichens Wirth (1995). Within each plot, aboveground biomass was sampled in a circle with a diameter of $29.5 \mathrm{~cm}$. Within each circle, thickness of the humus horizon (Ol, Of, Oh) was measured (Finnern and others 1994). Below this, a soil sample mixed out of three soil cores (each core cutter $100 \mathrm{~cm}^{3}$ ) was collected from the top $10 \mathrm{~cm}$ of the mineral soil layer. In addition, at each site, three soil samples (top $2-3 \mathrm{~cm}$ ) were

Table 2. Classification of Field Sites

\begin{tabular}{|c|c|c|c|c|c|c|}
\hline \multirow[t]{2}{*}{ Field site } & \multirow{2}{*}{$\begin{array}{l}\text { Parent } \\
\text { sand, pH }\end{array}$} & \multirow[t]{2}{*}{ pH, class } & \multicolumn{2}{|c|}{ Lichen-N, \% } & \multirow{2}{*}{$\begin{array}{l}\text { Calc. total N, } \\
\mathrm{kg} \mathrm{ha}^{-1} \mathrm{y}^{-1}\end{array}$} & \multirow[t]{2}{*}{ Deposition } \\
\hline & & & Mean & SE & & \\
\hline Keibu & 5.64 & Acid & 0.409 & 0.020 & 2.57 & Low \\
\hline Pärispea & 5.82 & Acid & 0.425 & 0.016 & 3.12 & Low \\
\hline Syrodde & 5.30 & Acid & 0.451 & 0.017 & 4.02 & Low \\
\hline Sandhammaren & 5.27 & Acid & 0.463 & 0.015 & 4.39 & Low \\
\hline Korshage & 5.43 & Acid & 0.497 & 0.026 & 5.54 & High \\
\hline Dunenheide & 5.63 & Acid & 0.522 & 0.019 & 6.39 & High \\
\hline Torsö & 5.09 & Acid & 0.537 & 0.020 & 6.89 & High \\
\hline Gellen & 5.02 & Acid & 0.545 & 0.017 & 7.19 & High \\
\hline Tönnersa & 5.50 & Acid & 0.554 & 0.032 & 7.48 & High \\
\hline Nagliu & 6.82 & Slightly calcareous & 0.404 & 0.018 & 2.41 & Low \\
\hline Akmensrags & 6.98 & Slightly calcareous & 0.428 & 0.025 & 3.23 & Low \\
\hline Nidda & 6.87 & Slightly calcareous & 0.439 & 0.022 & 3.60 & Low \\
\hline Pavilosta & 6.85 & Slightly calcareous & 0.448 & 0.016 & 3.91 & Low \\
\hline Harilaid & 6.59 & Slightly calcareous & 0.484 & 0.017 & 5.10 & High \\
\hline Holtemmen & 6.15 & Slightly calcareous & 0.496 & 0.019 & 5.53 & High \\
\hline Łeba & 6.79 & Slightly calcareous & 0.504 & 0.023 & 5.81 & High \\
\hline Pajuris & 6.42 & Slightly calcareous & 0.505 & 0.015 & 5.82 & High \\
\hline Raghammer & 6.63 & Slightly calcareous & 0.513 & 0.013 & 6.10 & High \\
\hline Pape & 6.54 & Slightly calcareous & 0.562 & 0.017 & 7.76 & High \\
\hline
\end{tabular}

Sites with $\mathrm{pH}_{\mathrm{NaCl}}$ above 6.0 of the parent sand material are classified as 'slightly calcareous' sites with $\mathrm{pH}$ NaCl below 6.0 as 'acid'. Sites with calculated total wet $\mathrm{N}$-deposition below $5 \mathrm{~kg} \mathrm{~N} \mathrm{ha}^{-1} \mathrm{y}^{-1}$ are classified as $\mathrm{N}$-unaffected or 'low' $\mathrm{N}$-deposition sites, sites with calculated total wet $\mathrm{N}$-deposition above $5 \mathrm{~kg} \mathrm{~N}$ ha ${ }^{-1} y^{-1}$ as $\mathrm{N}$-affected or 'high' $\mathrm{N}$ deposition sites. Total deposition of $N$ was calculated using the lichen biomonitor (calc. total $N$; method see Remke and others 2009). 
taken along the first dune ridge towards the open sea to determine the $\mathrm{pH}$ of the parent sand material. All samples were dried at $70^{\circ} \mathrm{C}$ (plant) and $40^{\circ} \mathrm{C}$ (soil) for $24 \mathrm{~h}$.

The lichen, Cladonia portentosa (Dufour) Coem., was used as biomonitor for atmospheric $\mathrm{N}$ deposition (Remke and others 2009). Within each plot, ten $10 \times 10 \mathrm{~cm}^{2}$ samples of C. portentosa were cut with a pair of scissors out of the center of a lichen patch of approximately $0.4-0.5 \mathrm{~m}$ diameter (Søchting 1995). Only the top $2 \mathrm{~cm}$ of the Cladonia were collected to exclude nutrient uptake from the soil. The samples were cleaned roughly and stored in a paper bag. In the laboratory, all samples were cleaned thoroughly, washed briefly in distilled water and dried at $70^{\circ} \mathrm{C}$ for $24 \mathrm{~h}$.

Fresh biomass was separated into cryptogams (lichens and mosses), vascular plants and litter, and weighed after drying at $70^{\circ} \mathrm{C}$ for $24 \mathrm{~h}$. A subsample of sand sedge was taken for further analysis. Sand sedge and Cladonia portentosa samples were ground in a centrifugal mill (rotational speed 18,000 for 1-2 $\times$ min, FRITSCH pulverisette 14, Idar-Oberstein, Germany). Total nitrogen and $\mathrm{CN}$-ratio of plant and soil material (finely ground in a centrifugal ball mill, Fritsch, Idar-Oberstein, Germany) were determined with a $\mathrm{C} / \mathrm{N}$-analyzer (CHNOS element analyzer vario EL III, elementar Analysensysteme, Hanau, Germany). Total P was analyzed for sand sedge only, with $200 \mathrm{mg}$ ground material digested in sealed Teflon vessels in a Milestone microwave oven (type Ethos D, Milestone Inc., Sorisole, Italy) after addition of $4 \mathrm{ml} \mathrm{HNO}_{3}(65 \%)$ and $1 \mathrm{ml} \mathrm{H}_{2} \mathrm{O}_{2}(30 \%)$ (Kingston and Haswell 1997).

Soil samples were sieved with a $2 \mathrm{~mm}$ mesh-size before the following analyses. Soil organic matter content was determined as loss on ignition (LOI) at $550^{\circ} \mathrm{C}$ for $8 \mathrm{~h}$, and $\mathrm{pH}$ was measured in $0.2 \mathrm{M} \mathrm{NaCl}$. Total extractable amounts of $\mathrm{Al}, \mathrm{Ca}$, $\mathrm{Fe}, \mathrm{Mg}, \mathrm{Mn}, \mathrm{P}, \mathrm{S}$, and $\mathrm{Zn}$ were measured in these $0.2 \mathrm{M} \mathrm{NaCl}$ extracts, and $\mathrm{Na}$ in a double deionized water extract with inductively coupled plasma emission spectrophotometry (ICP-OES: IRIS Intrepid II XDL, Thermo Fisher Electric, Breda, The Netherlands). Nitrogen mineralization was measured in a laboratory incubation experiment of 26 days, with $60 \mathrm{~g}$ of sieved soil in glass beakers sealed with parafilm kept at $40 \%$ water holding capacity and $25^{\circ} \mathrm{C}$ in total darkness. $\mathrm{NO}_{3}{ }^{-}$and $\mathrm{NH}_{4}{ }^{+}$were measured at the start and end of the incubation period, using extractions with double deionized water and $0.2 \mathrm{M} \mathrm{NaCl}$, respectively. Ortho-P was measured in double deionized water extracts at the start of the incubation period. Nitrate, ammonium and phosphate were measured colorimetrically with an Auto Analyzer 3 system (Bran + Luebbe, Norderstedt, Germany), using ammonium molybdate (Henriksen 1965), hydrazine sulphate (Technicon 1969) and salicylate (Grasshoff and Johannsen 1977), respectively.

Linear models and linear mixed effect models were fitted using $\mathrm{R}$ ( $\mathrm{R}$ Development Core Team 2008), followed by model justification procedures. Mixed effect models were applied to overcome spatial pseudo-replication within the dataset (field site as random factor). If fitted models were not justified, generalized linear models (glm) with gamma error distributions were fitted or data were transformed by log or (double) square root before regression analysis. Multiple regressions were carried out starting with all environmental factors and subsequently simplified using stepwise backward deletion until the minimal adequate model was reached. To avoid over-dispersion no more variables than the replicate number divided by three were fitted (Crawley 2005, 2007). Tests between two classes were performed by Student's $t$ test, if the data were normally distributed, otherwise the non-parametric Kruskal-Wallis test was performed.

\section{Results}

\section{Acidification}

Acidification rates differed between early and later successional stages. Initial acidification, that is, differences in $\mathrm{pH}$ between parent material and the first succession stage, was negatively correlated with acidification during subsequent succession (Figure 2). At sites with small $\mathrm{pH}$ differences between parent material and the first stage of succession, the $\mathrm{pH}$ decreased by nearly two units during the succession from the first to the third stage. Sites following this pattern were Akmensrags, Nagliu, Pajuris, Syrodde, Pape and Gellen (Figure 2). Sites with high $\mathrm{pH}$ differences $(\sim 2$ units) between parent material and initial succession stage, showed minimal $\mathrm{pH}$ decrease with further succession. Dünenheide, Harilaid, Pavilosta, Holtemmen, Keibu and Korshage were examples for this pattern. The early acidification, that is, the high $\mathrm{pH}$-decrease between the parent sand material and the first stage, shows no link to $\mathrm{N}$-deposition levels. The early decrease in $\mathrm{pH}$ (parent sand-first stage) cannot be linked to $\mathrm{N}$-deposition (regression results: acid $P=0.595$; slightly calcareous $P=0.845 ;$ all $P=0.660$ ). Only the $\mathrm{pH}$ itself differed with $\mathrm{N}$-deposition. Especially at acid sites and later successional stages the $\mathrm{pH}$ was significantly lower (0.3-0.5 units) at $\mathrm{N}$-affected sites (Table 3). 


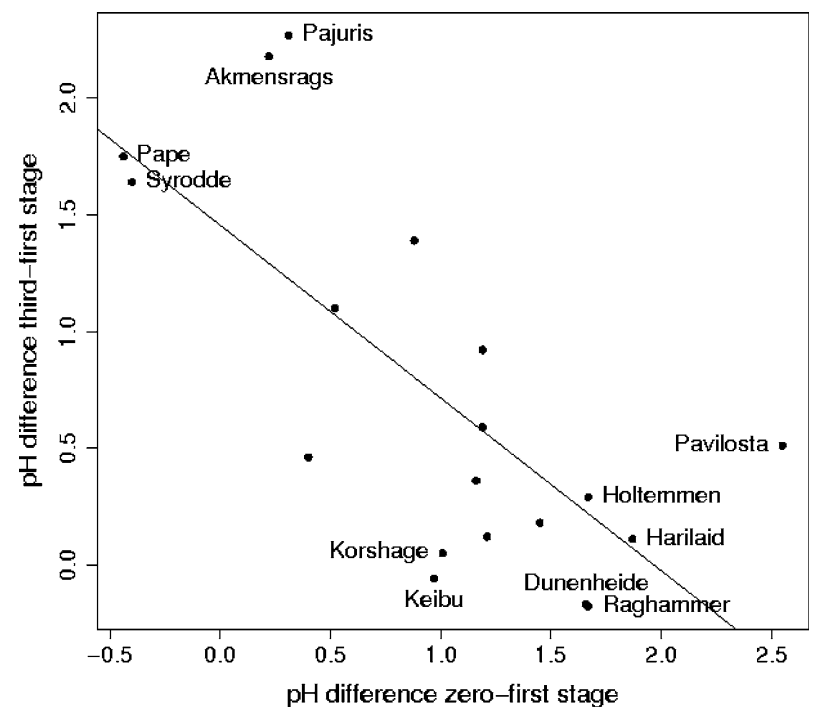

Figure 2. Relationship between the $\mathrm{pH}$ difference of the parent sand material and the first vegetation succession stage and the $\mathrm{pH}$ difference within succession, that is, first and the third succession stage. Every point is a site and extreme sites are labelled. For example, Pajuris or Akmensrags have a low pH decrease between the parent sand material and the first succession stage, and Pavilosta and Harilaid have a high $\mathrm{pH}$ difference within later succession (regression equation: $y=-0.74 x+1.45, R^{2}=$ $0.5166, P=0.001)$.

\section{Eutrophication}

Soil pH and organic matter (LOI) were closely related and changed during succession, but were also affected by $\mathrm{N}$-deposition (Figure 3). Organic matter increased exponentially with decreasing $\mathrm{pH}$, but only in areas with high $\mathrm{N}$-deposition. Plots with more than $1.0-1.5 \%$ soil organic matter and a $\mathrm{pH}$ below 4.0 belonged mainly to the third succession stage at $\mathrm{N}$-affected sites, which are densely covered by Carex arenaria. A significant increase in organic matter with $\mathrm{N}$-deposition occurred only at sites with acid parent material (Table 3). At these sites, organic matter concentration was two to four times higher at $\mathrm{N}$-affected than at $\mathrm{N}$-unaffected sites. At sites with slightly calcareous parent material, however, organic matter increased during succession, but did not differ between low and high $\mathrm{N}$-deposition areas (Table 3).

During succession, net $\mathrm{N}$-mineralization generally increased from the first to the third stage (Table 3). The amount of $\mathrm{N}$-mineralization per unit soil organic matter was positively correlated with $\mathrm{pH}$ (Figure 4) and furthermore related to $\mathrm{N}$-deposition. The increase of $\mathrm{N}$-mineralization/LOI with increasing $\mathrm{pH}$ was three times steeper at $\mathrm{N}$-affected than at N-unaffected sites (Figure 4), and N-min- eralization in total was elevated two to three times at sites with high $\mathrm{N}$ deposition (Table 3).

\section{Toxicity}

The Al/Ca-ratio increased with increasing $\mathrm{N}$-deposition only at sites with acid parent material (second stage, Table 4), and was twice as high at $\mathrm{N}$ affected than at $\mathrm{N}$-unaffected sites (second stage, Table 3). At acid sites, the Al/Ca-ratio exceeded the values of one in all succession stages. At sites with slightly calcareous parent material, Al/Ca-ratios were 5-10 times lower. Salt-extractable Fe soil concentrations were at least two times higher at acid than at slightly calcareous sites. At acid sites, the Fe content was 1.5-3 times higher under high compared to low $\mathrm{N}$-deposition.

\section{Characteristics of Carex arenaria Plants and Vegetation Stands}

Increased atmospheric $\mathrm{N}$-deposition (measured as lichen-N) was positively correlated to the $\mathrm{N}$-content of Carex tissue, but only in early succession stages at acid sites and all sites pooled (Table 4). N/P-ratios (Carex) were positively correlated to $\mathrm{N}$-deposition in all three succession stages at acid sites (Table 4). Tissue P-concentrations of Carex arenaria did not differ among sites or succession stages,

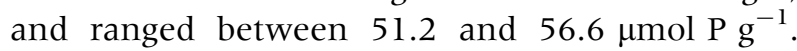
There was no significant relationship between tissue- $\mathrm{N}$ of Carex and total $\mathrm{N}, \mathrm{NH}_{4}{ }^{+}$or $\mathrm{NO}_{3}{ }^{-}$in the soil.

At acid sites, cover of Carex arenaria significantly increased under $\mathrm{N}$-affected conditions in later stages of succession (Tables 3 and 4, Figure 5). Carex cover was 1.5-2 times higher under N-affected conditions. In early stages, or slightly calcareous sites, Carex cover was not affected by Ndeposition. In the third succession stage, Carex cover was negatively correlated to species numbers of lichens and mosses $(y=-0.09 x+8.48, \quad P=$ 0.000 ) and positively to total biomass of vascular plants $(y=0.47 x+33.70, P=0.027)$. Carex cover was not significantly correlated to soil organic matter. Furthermore, longitude, latitude, climate data (temperature, precipitation) and salinity were not significantly correlated to Carex cover in multiple regression.

\section{Species Richness}

At acid sites, the species number of foliose lichens, as well as number of all lichen species together (second and third stage; Figure 6), and grasses and forbs (third stage) were significantly lower (two to three species) under high $\mathrm{N}$-deposition (Table 5). 
Table 3. Soil and Plant Data for All Sites, Separated for pH Classes (Acid, Slightly Calcareous), Deposition Classes (N-Unaffected and N-Affected) and Vegetation Succession Stages (First, Second and Third stage)

\begin{tabular}{|c|c|c|c|c|c|c|}
\hline \multirow{2}{*}{$\begin{array}{l}\text { Deposition } \\
\text { Succession stage }\end{array}$} & \multicolumn{3}{|l|}{ N-unaffected } & \multicolumn{3}{|l|}{$\mathrm{N}$-affected } \\
\hline & First & Second & Third & First & Second & Third \\
\hline \multicolumn{7}{|l|}{ Acid sites } \\
\hline Lichen-N, \% & $0.428(0.06)$ & $0.437(0.06)$ & $0.463(0.00)$ & $0.541(0.03)$ & $0.531(0.06)$ & $0.533(0.05)$ \\
\hline LOI, \% & $0.28(0.03)$ & $0.50(0.05)$ & $0.41(0.03)$ & $0.38(0.07)$ & $1.15(0.19)$ & $1.46(0.26)$ \\
\hline $\mathrm{Ol}, \mathrm{cm}$ & $0.1(0.04)$ & $0.3(0.05)$ & $0.4(0.10)$ & $0.0(0.00)$ & $0.10(0.04)$ & $0.8(0.10)$ \\
\hline $\mathrm{pH}, \mathrm{NaCl}$ & $4.91(0.31)$ & $4.25(0.11)$ & $3.94(0.02)$ & $4.27(0.08)$ & $3.74(0.06)$ & $3.67(0.09)$ \\
\hline C/N-ratio soil & $10.9(1.2)$ & $11.6(0.6)$ & $11.8(1.6)$ & $8.7(0.9)$ & $14.2(0.7)$ & $13.5(0.9)$ \\
\hline $\mathrm{N}$-miner., $\mathrm{g} / \mathrm{m}^{3}$ & $0.69(0.12)$ & $0.84(0.12)$ & $0.87(0.19)$ & $1.27(0.16)$ & $1.69(0.21)$ & $2.65(0.36)$ \\
\hline $\mathrm{N}-\mathrm{NH}_{4}, \mathrm{~g} / \mathrm{m}^{3}$ & $0.56(0.11)$ & $0.78(0.11)$ & $0.81(0.22)$ & $0.91(0.13)$ & $0.93(0.06)$ & $1.22(0.12)$ \\
\hline $\mathrm{N}-\mathrm{NO}_{3}, \mathrm{~g} / \mathrm{m}^{3}$ & $1.20(0.30)$ & $2.29(0.70)$ & $0.99(0.28)$ & $2.41(0.63)$ & $3.84(0.86)$ & $5.41(1.08)$ \\
\hline $\mathrm{NH}_{4} / \mathrm{NO}_{3}$ ratio & $0.57(0.1)$ & $0.74(0.2)$ & $0.92(0.3)$ & $0.54(0.1)$ & $0.49(0.1)$ & $0.36(0.1)$ \\
\hline $\mathrm{Al} / \mathrm{Ca}$-ratio soil & $1.27(0.41)$ & $0.40(0.13)$ & $0.42(0.1)$ & $1.19(0.2)$ & $1.04(0.2)$ & $0.98(0.39)$ \\
\hline $\mathrm{Fe}, \mu \mathrm{mol} / \mathrm{kg}$ & $9.03(1.96)$ & $20.56(3.26)$ & $40.28(2.12)$ & $13.00(1.97)$ & $65.73(11.32)$ & $74.42(14.54)$ \\
\hline $\mathrm{CEC}, \mu \mathrm{mol} / \mathrm{kg}$ & $1190(504)$ & $1276(270)$ & $662(106)$ & $624(142)$ & $1250(431)$ & 1781 (317) \\
\hline Ortho-P, $\mu \mathrm{mol} / \mathrm{kg}$ & $9.98(2.05)$ & $24.70(5.14)$ & $42.49(5.08)$ & $27.53(7.17)$ & $31.22(8.13)$ & $63.18(8.69)$ \\
\hline N/P-ratio Carex & $7.8(1.1)$ & $7.1(0.4)$ & $8.1(0.1)$ & $11.5(0.5)$ & $9.6(0.5)$ & $9.6(0.5)$ \\
\hline N Carex, \% & $11.43(0.54)$ & $11.72(0.99)$ & $12.95(1.05)$ & $17.48(1.44)$ & $14.61(0.54)$ & $15.29(0.63)$ \\
\hline P Carex, \% & $1.71(0.35)$ & $1.67(0.12)$ & $1.62(0.15)$ & $1.59(0.18)$ & $1.56(0.09)$ & $1.62(0.08)$ \\
\hline Carex cover per plot, \% & $2.9(1.1)$ & $6.2(2.0)$ & $47.7(10.2)$ & $5.6(1.4)$ & $12.3(2.1)$ & $77.1(4.7)$ \\
\hline Vascular plant biomass, $\mathrm{g} / \mathrm{m}^{2}$ & $66.8(14.1)$ & $219.4(63.4)$ & $954.8(107.8)$ & $78.7(10.4)$ & $539.5(164.6)$ & $1066.4(94.9)$ \\
\hline Lichen and moss biomass, $\mathrm{g} / \mathrm{m}^{2}$ & $16.7(11.1)$ & $768.3(120.4)$ & $51.8(32.9)$ & $13.1(5.6)$ & $868.3(173.3)$ & $371.2(170.7)$ \\
\hline \multicolumn{7}{|l|}{ Slightly calcareous sites } \\
\hline Lichen-N, \% & $0.441(0.07)$ & $0.442(0.08)$ & $0.441(0.07)$ & $0.516(0.06)$ & $0.516(0.06)$ & $0.519(0.08)$ \\
\hline LOI, \% & $0.31(0.03)$ & $0.74(0.11)$ & $0.89(0.07)$ & $0.26(0.05)$ & $0.64(0.08)$ & $0.84(0.14)$ \\
\hline $\mathrm{Ol}, \mathrm{cm}$ & $0.05(0.02)$ & $0.80(0.18)$ & $1.28(0.22)$ & $0.07(0.04)$ & $0.59(0.11)$ & $1.25(0.23)$ \\
\hline $\mathrm{pH}, \mathrm{NaCl}$ & $5.58(0.26)$ & $4.90(0.24)$ & $4.73(0.2)$ & $5.70(0.3)$ & $4.74(0.2)$ & $4.57(0.21)$ \\
\hline $\mathrm{C} / \mathrm{N}$-ratio soil & $16.0(3.4)$ & $12.0(0.7)$ & $12.0(0.62)$ & $12.0(0.87)$ & $12.7(0.93)$ & $13.5(0.72)$ \\
\hline $\mathrm{N}$-miner., $\mathrm{g} / \mathrm{m}^{3}$ & $1.19(0.11)$ & $1.38(0.36)$ & $3.00(0.37)$ & $1.10(0.15)$ & $1.81(0.27)$ & $3.33(0.64)$ \\
\hline $\mathrm{N}-\mathrm{NH}_{4}, \mathrm{~g} / \mathrm{m}^{3}$ & $0.35(0.08)$ & $0.65(0.12)$ & $1.05(0.09)$ & $0.42(0.06)$ & $0.52(0.11)$ & $0.90(0.17)$ \\
\hline $\mathrm{N}-\mathrm{NO}_{3}, \mathrm{~g} / \mathrm{m}^{3}$ & $1.19(1.08)$ & $5.17(1.30)$ & $4.08(0.88)$ & $1.02(0.69)$ & $4.24(0.63)$ & $3.20(1.33)$ \\
\hline $\mathrm{NH}_{4} / \mathrm{NO}_{3}$ ratio & $0.25(0.1)$ & $2.00(0.8)$ & $0.35(0.05)$ & $0.16(0.03)$ & $1.02(0.44)$ & $0.42(0.14)$ \\
\hline $\mathrm{Al} / \mathrm{Ca}$-ratio soil & $0.74(0.4)$ & $0.12(0.1)$ & $0.71(0.6)$ & $0.07(0.03)$ & $0.19(0.11)$ & $0.08(0.02)$ \\
\hline $\mathrm{Fe}, \mu \mathrm{mol} / \mathrm{kg}$ & $4.86(0.66)$ & $13.24(2.69)$ & $24.81(5.64)$ & $5.46(1.08)$ & $18.32(4.79)$ & $22.04(4.81)$ \\
\hline $\mathrm{CEC}, \mu \mathrm{mol} / \mathrm{kg}$ & $1353(224)$ & $2600(342)$ & $2663(342)$ & 1141 (127) & $1915(274)$ & $2356(320)$ \\
\hline Ortho-P, $\mu \mathrm{mol} / \mathrm{kg}$ & $12.20(1.60)$ & $49.68(13.57)$ & $54.52(9.84)$ & $22.78(7.37)$ & $64.37(12.71)$ & $70.39(14.83)$ \\
\hline N/P-ratio Carex & $9.9(0.7)$ & $7.9(0.5)$ & $7.9(0.4)$ & $9.3(0.6)$ & $7.8(0.4)$ & $7.0(0.28)$ \\
\hline $\mathrm{N}$ Carex, \% & $13.02(0.42)$ & $12.41(0.46)$ & $13.27(0.77)$ & $14.91(0.65)$ & $12.76(0.38)$ & $13.71(0.61)$ \\
\hline P Carex, \% & $1.40(0.09)$ & $1.62(0.08)$ & $1.73(0.13)$ & $1.76(0.20)$ & $1.73(0.09)$ & $1.99(0.12)$ \\
\hline Carex cover per plot, \% & $4.3(0.7)$ & $5.8(0.8)$ & $60.6(2.5)$ & $4.9(1.1)$ & $7.0(1.2)$ & $65.1(3.29)$ \\
\hline Vascular plant biomass, $\mathrm{g} / \mathrm{m}^{2}$ & $86.3(9.0)$ & $233.7(41.0)$ & $905.0(68.0)$ & $84.4(10.2)$ & $238.5(30.4)$ & $897.9(78.7)$ \\
\hline Lichen and moss biomass, $\mathrm{g} / \mathrm{m}^{2}$ & $18.6(11.6)$ & $893.0(80.6)$ & $180.8(72.0)$ & $29.3(19.0)$ & $844.1(97.3)$ & $147.1(68.5)$ \\
\hline
\end{tabular}

$L O I=$ loss on ignition, $\mathrm{Ol}=$ thickness of litter layer, $\mathrm{CEC}=$ cation exchange capacity

Values are arithmetic means $( \pm 1 S E)$. Significant differences $(P<0.05)$ between deposition classes $(N$-affected and N-unaffected) are shown in bold.

Foliose lichens such as Cladonia glauca Flörke, Cl. macilenta (Leighton) Arnold, Cl. coccifera (L.) Willd. and Cetraria aculeata (Schreber) Fr./muricata (Ach.) Eckfeldt, grasses such as Festuca polesica Zapał. and Ammophila arenaria (L.). Link, and forbs such as Hypochaeris radicata L., Thymus serpyllum L. and Hieracium umbellatum L. were absent or had lower cover at $\mathrm{N}$-affected sites. In contrast, Carex arenaria and Corynephorus canescens were more abundant at acid sites with high $\mathrm{N}$-deposition, and Rumex acetosella L. was exclusively found at these sites.

The most important predictors for the decrease in species numbers at acid sites were selected with multiple regression. For the second succession stage, the model explained $20-50 \%$ of the variance, with $\mathrm{Al} / \mathrm{Ca}$-ratio and its (statistical) interaction 


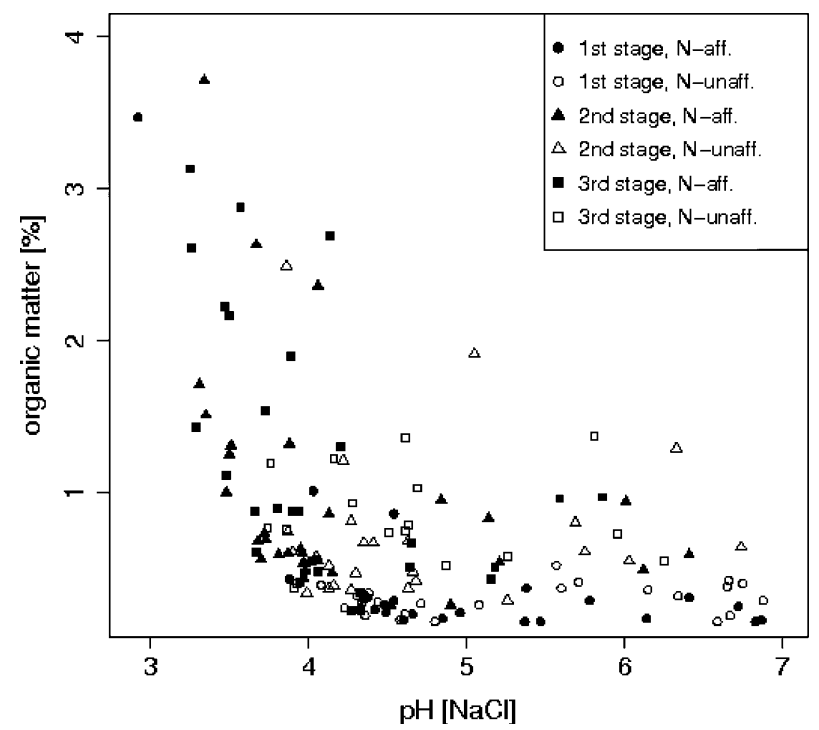

Figure 3. Organic matter content (LOI) versus pH of all vegetation units.

with $\mathrm{pH}$ and $\mathrm{N}$-deposition as most important factors. For the third stage, only $\mathrm{N}$-deposition was a significant predictor for species richness and explained $30-60 \%$ of the variance (Table 6). Species with preference for low Al/Ca-ratios were Hieracium umbellatum (higher coverage), Cladonia glauca (higher coverage and occurrence), and Jasione montana L., Cladonia coccifera and Cladonia floerkeana (Fr.) V.Wirth (higher occurrence). Species excluded from sites with high $\mathrm{Al} / \mathrm{Ca}$-ratios were Cladonia glauca, Viola ssp. and Luzula ssp. However, Rumex acetosella, Anthoxanthum odoratum L. and Corynephorus canescens were more abundant at high $\mathrm{Al} /$ Ca-ratios.

At sites with slightly calcareous parent material, the effect of $\mathrm{N}$-deposition was less pronounced than at acid sites, and even slightly positive for overall species richness (Table 5). In multiple regression, $\mathrm{Al} / \mathrm{Ca}$-ratio and $\mathrm{pH}$ mainly determined species richness (Table 6). $\mathrm{N}$-affected sites had one species of foliose lichen (third stage), grass (second stage) and forb (first stage) more, but one moss species less (second stage). Cladonia coniocrea auct. (foliose lichen), Hypochaeris radicata (forb), Anthoxanthum odoratum and Festuca rubra L. (grasses) were more abundant at high $\mathrm{N}$-deposition. Dicranum scoparium Hedw. (second stage) had exceptionally high coverages $(30-40 \%)$ at high $\mathrm{N}$-deposition. However, Pleurozium schreberi (Brid.) Mitt. (moss), Cetraria aculeata/muricata and C. islandica (L.) Ach. (first and second stage) occurred only at $\mathrm{N}$-unaffected sites.
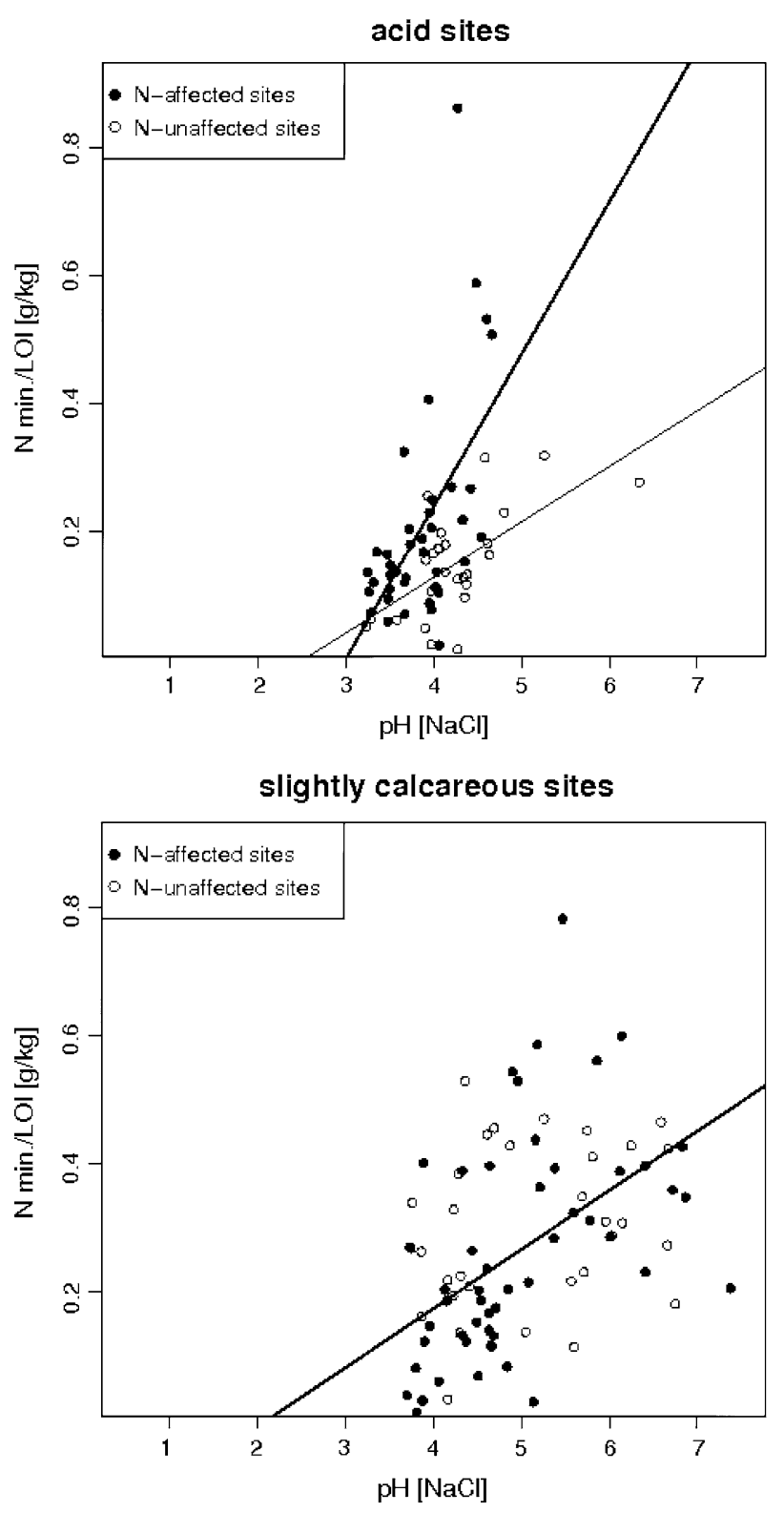

Figure 4. N-mineralization per day per LOI $\left(\mathrm{g} \mathrm{kg}^{-1}\right)$ against the $\mathrm{pH}(\mathrm{NaCl})$ for acid and slightly calcareous sites separately. (Regression results: acid sites: $\mathrm{N}$-affected $y=$ $0.238 x-0.712 \quad(P=0.000), \quad \mathrm{N}$-unaffected $y=0.087 x$ $-0.218(P=0.001)$; slightly calcareous sites: $\mathrm{N}$-affected $y=0.092 x-0.194(P=0.005), \mathrm{N}$-unaffected not regression equation as $P=0.104)$.

\section{Discussion}

\section{Which Processes Change During Grass Encroachment?}

At these 19 coastal dune sites within the Baltic Sea region even medium loads of wet $\mathrm{N}$-deposition (5-8 $\mathrm{kg} \mathrm{N} \mathrm{ha}^{-1} \mathrm{y}^{-1}$ ) have an impact on soil and 
Table 4. Regression Results of Various Factors (Dependent Factor) with Atmospheric N-Deposition (Measured as Lichen-N; Independent Factor)

\begin{tabular}{|c|c|c|c|c|c|}
\hline Depending factor & Acid sites & & $\begin{array}{l}\text { Slightly } \\
\text { calcareous }\end{array}$ & All sites & \\
\hline PH-difference parent sand-First stage & & $P=0.595$ & $P=0.845$ & & $P=0.660$ \\
\hline $\mathrm{Al} / \mathrm{Ca}-$ ratio (second stage) & $y=0.85 x-3.34$ & $P=0.034$ & $P=0.807$ & & $P=0.179$ \\
\hline Carex tissue $\mathrm{N}$ (first stage) & & & $P=0.196$ & $5 x-2.10$ & $P=0.021$ \\
\hline Carex tissue $\mathrm{N}$ (second stage) & $y=2.79 x-0.73$ & $P=0.040$ & $P=0.446$ & $y=1.74 x+4.35$ & $P=0.013$ \\
\hline Carex tissue N/P-ratio (first stage) & $y=3.86 x-8.95$ & $P=0.013$ & $P=0.919$ & $y=1.93 x-0.48$ & $P=0.058$ \\
\hline Carex tissue N/P-ratio (second stage) & $y=2.53 x-4.10$ & $P=0.012$ & $P=0.331$ & $y=1.83 x-0.84$ & $P=0.009$ \\
\hline Carex tissue N/P-ratio (third stage) & $y=3.23 x-7.53$ & $P=0.047$ & $P=0.778$ & & $P=0.122$ \\
\hline Carex cover [\%] (third stage) & $y=7.90 x-29.07$ & $P=0.039$ & $P=0.806$ & $y=4.72 x-14.92$ & $P=0.040$ \\
\hline
\end{tabular}

Climatic factors (temperature, precipitation), salinity and UTM-coordinates had no significant impact in multiple regression. Regression results of the listed factors were not significant in other successional stages and are not shown.

vegetation factors. At these medium $\mathrm{N}$-loads factors are changing significantly only at acid sites (parent sand $\mathrm{pH}<6.0$ ) not at slightly calcareous sites (parent sand $\mathrm{pH}>6.0$ ). The $\mathrm{pH}$ of the parent sand material is a main factor responsible for the reaction of the system to these low to medium N-loads. Although pH-differences are small between acid and slightly calcareous sites, they determine which buffer range is acting and how quickly the buffering capacity of cations is depleted, if toxic levels of soluble metals can occur or if mineralization processes are hampered.

The acidity of the soil has a major influence on soil processes. Some field sites show the expected pattern of acidification during vegetation succession in coastal dunes. The $\mathrm{pH}$ remains almost constant during the transition from parent sand material to first stage, but decreases with increasing successional age (Ellenberg 1996). In contrast to these are sites where the $\mathrm{pH}$ decreases already between the parent sand material and the first succession stage, after which it remains stable. This $\mathrm{pH}$ reduction during the early successional stages was not correlated to $\mathrm{N}$ deposition, but may instead be caused by anthropogenic sulphur deposition, for example, ship traffic. Sulphur generally generates two times more protons than reduced or oxidized nitrogen (NEGTAP 2001). Pure chemical reactions might prevail in the pure sands at initial successional stages, whereas biological transformations of $\mathrm{N}$ such as nitrification may dominate the acidifying processes in later succession stages with higher soil organic matter contents. This is supported by the lower $\mathrm{pH}$ values of later successional stages at higher $\mathrm{N}$-deposition in this study.

As soil pH decreases, organic matter (LOI) accumulates exponentially (this paper; Stützer 1998; Scheffer and Schachtschabel 1998). In these dry, oligotrophic systems, organic matter retains moisture and stabilizes the soil micro-climate. Most typical dry dune plant species are adapted to fluctuating, extreme temperatures, drought and frequent soil moisture changes. The more stabilized conditions, which prevail during organic matter accumulation, support the growth of ruderal, nitrophilous species at the cost of typical dry dune species like Jasione montana. Graminoids such as Carex arenaria, Calamagrostis epigejos and Festuca rubra become dominant, where a sufficient layer of organic matter is available or the top sand layer is nutrient rich (Boorman and Van der Maarel 1997). This observation is supported by the current dataset. At acid sites, the total standing vascular plant biomass and the cover of $C$. arenaria are 1.5-3 times higher at $\mathrm{N}$-affected than at $\mathrm{N}$-unaffected sites.

At older successional stages, the higher $\mathrm{N}$-content and N/P-ratio in Carex tissue at $\mathrm{N}$-affected sites is in contrast with the higher $\mathrm{C} / \mathrm{N}$-ratio in the soil. Different explanations are possible. One is that surplus mineralized $\mathrm{N}$ is taken up directly by Carex. In addition, in acid soils more $\mathrm{N}$ might be available for vascular plants in competition with microbes as microbial communities seem to have a lower demand for N (Kooijman and Besse 2002; Kooijman and others 2008). Another possible explanation is, that $\mathrm{NO}_{3}{ }^{-}$, which is not taken up, is readily leached. Furthermore, the immobilized $\mathrm{N}$ can be bound in structures with higher $\mathrm{C} / \mathrm{N}$-ratios like fungi in these acid soils, which might then result in a higher $\mathrm{C} / \mathrm{N}$-ratio for the total soil.

Although nitrification is hampered at a $\mathrm{pH}$ below 4.2 (Aerts and Bobbink 1999; Roelofs and others 1985), the higher amount of organic matter at acid, $\mathrm{N}$-affected sites nevertheless increases $\mathrm{N}$ mineralization to the same level as at slightly calcareous sites (Table 3). At acid sites, microbes have 


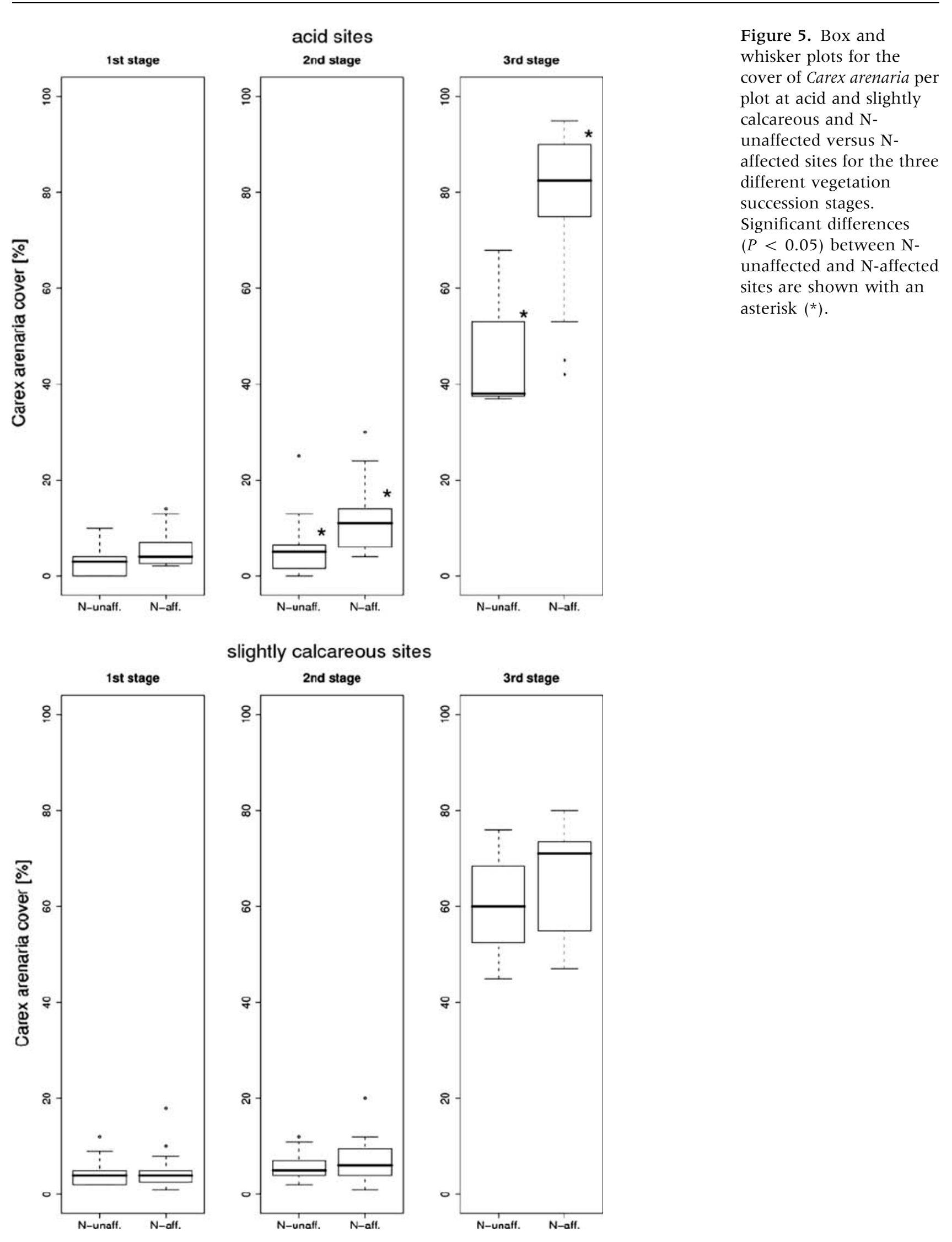




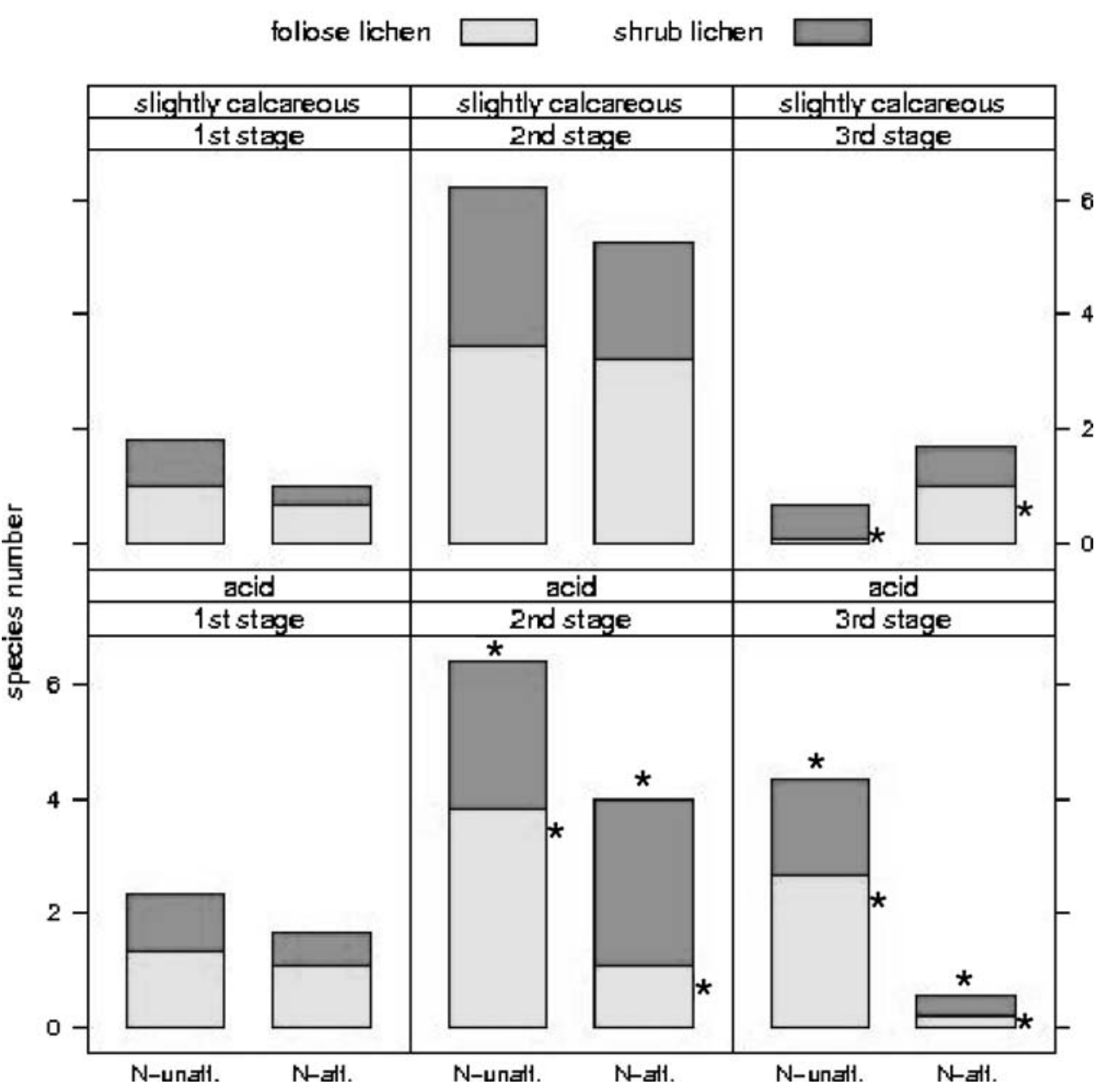

Figure 6. Species number of foliose, shrub and total lichen (per $4 \mathrm{~m}^{2}$ plot) at acid and slightly calcareous and $\mathrm{N}$ unaffected versus $\mathrm{N}$ affected sites for the three different vegetation succession stages. Significant differences $(P<0.05)$ between $\mathrm{N}$ unaffected and $\mathrm{N}$-affected sites are shown with an asterisk $\left(^{*}\right)$ beside each bar for different lichen groups and on the top of the bar for total lichen species number (foliose and shrub lichen data pooled). a lower demand for $\mathrm{N}$, and therefore the net availability of $\mathrm{N}$ for vascular plants, for example, Carex, seems to be higher.

$\mathrm{Al} / \mathrm{Ca}$-ratios as well as available Fe concentrations are higher at $\mathrm{N}$-affected, acid sites compared to $\mathrm{N}$-unaffected sites. Carex which is more abundant at these sites seems not to be hampered by these high metal concentrations, though metal toxicity might inhibit the growth of many typical plants of dry, lichen-rich dune grasslands. In addition, Carex can grow taller and has greater growth plasticity (Tietema 1981) than typical dry dune grassland species, and can thus dominate the system.

A N/P-ratio of 7-12 indicates that Carex is far from being P-limited and still N-limited (Koerselman and Meuleman 1996). This is supported by the total tissue concentration of $\mathrm{P}$ in Carex. P-limitation and critical values depend on plant species and plant tissue part, but a tissue concentration of 50-60 $\mu \mathrm{mol} \mathrm{P} \mathrm{g}{ }^{-1} \mathrm{dw}$, which is the range for Carex at these 19 sites, is critical but not severely limiting (Troelstra and others 2001).
Carex arenaria is therefore assumed to find optimal growth conditions in Baltic dune sites with high $\mathrm{N}$ deposition as it is not hampered by low $\mathrm{pH}$ conditions, but is favored by increased availability of its limiting nutrient, nitrogen. With its larger structure, C. arenaria can probably comb out more atmospheric $\mathrm{N}$ via its leaves as Ammophila arenaria does (Heil and others 1988). The N-content and N/P-ratio of Carex increase with rising N-deposition mainly at older successional stages, but no correlation was apparent between different soil $\mathrm{N}$-forms and Carex tissue N. At older successional stages, atmospheric $\mathrm{N}$ may therefore contribute more to the nutrition of Carex than soil-derived N. With its extensive rhizome network, $C$. arenaria can exploit and transport temporally and spatially widespread resources nearly all year round (Noble and Marshall 1983; D'Hertenfeld and Falkengren-Grerup 2002; D'Hertenfeld and Jonsdottir 1999) and thereby efficiently use the surplus nitrogen supply. C. arenaria finally wins the competition under higher N-loads. Organic matter content above $1.0-1.5 \%$ and $\mathrm{pH}$ below 4.0 might be the threshold 
Table 5. Species Richness for Different Life Forms Separated for Deposition Classes, pH Classes and Succession Stages

\begin{tabular}{|c|c|c|c|c|c|c|}
\hline & \multicolumn{3}{|c|}{ N-unaffected } & \multicolumn{3}{|c|}{$\mathrm{N}$-affected } \\
\hline & First & Second & Third & First & Second & Third \\
\hline \multicolumn{7}{|l|}{ Acid sites } \\
\hline Foliose lichens & $1.3(0.5)$ & $3.8(0.8)$ & $2.7(1.2)$ & $1.1(0.4)$ & $1.1(0.3)$ & $0.2(0.2)$ \\
\hline Shrub lichens & $1.0(0.4)$ & $2.6(0.4)$ & $1.7(0.9)$ & $0.5(0.3)$ & $2.9(0.4)$ & $0.4(0.2)$ \\
\hline All lichens & $2.3(0.9)$ & $6.4(0.7)$ & $4.3(1.5)$ & $1.6(0.5)$ & $4.0(0.5)$ & $0.6(0.2)$ \\
\hline Mosses & $0.8(0.2)$ & $1.8(0.3)$ & $1.3(0.3)$ & $1.0(0.3)$ & $1.4(0.2)$ & $0.6(0.3)$ \\
\hline Grasses & $2.6(0.4)$ & $3.0(0.4)$ & $3.7(0.3)$ & $2.9(0.4)$ & $3.4(0.3)$ & $2.0(0.2)$ \\
\hline Forbs & $1.6(0.6)$ & $3.1(0.4)$ & $2.3(0.7)$ & $0.2(0.1)$ & $3.7(0.6)$ & $0.9(0.3)$ \\
\hline Total & $7.2(1.2)$ & $14.2(1.1)$ & $11.7(2.4)$ & $5.7(0.9)$ & $12.5(0.7)$ & $4.1(0.7)$ \\
\hline \multicolumn{7}{|c|}{ Slightly calcareous sites } \\
\hline Foliose lichens & $1.0(0.5)$ & $3.5(0.8)$ & $0.1(0.1)$ & $0.7(0.3)$ & $3.2(0.7)$ & $1.0(0.5)$ \\
\hline Shrub lichens & $0.8(0.3)$ & $2.8(0.5)$ & $0.6(0.2)$ & $0.3(0.2)$ & $2.1(0.4)$ & $0.7(0.3)$ \\
\hline All lichens & $1.8(0.7)$ & $6.2(1.0)$ & $0.7(0.2)$ & $1.0(0.4)$ & $5.3(0.8)$ & $1.7(0.8)$ \\
\hline Mosses & $1.0(0.3)$ & $3.4(0.4)$ & $1.9(0.4)$ & $0.9(0.2)$ & $2.1(0.2)$ & $1.5(0.3)$ \\
\hline Grasses & $2.5(0.2)$ & $3.7(0.3)$ & $2.9(0.4)$ & $3.3(0.3)$ & $4.1(0.3)$ & $2.9(0.2)$ \\
\hline Forbs & $1.7(0.4)$ & $6.3(0.7)$ & $3.5(0.5)$ & $2.1(0.4)$ & $5.3(0.3)$ & $3.3(0.4)$ \\
\hline Total & $6.9(0.8)$ & $19.6(1.3)$ & $8.9(1.0)$ & $7.3(0.7)$ & $16.7(1.1)$ & $9.4(1.1)$ \\
\hline
\end{tabular}

Values are mean plus 1 SE in brackets; per $4 \mathrm{~m}^{2}$ plot.

Significant differences $(P<0.05)$ between deposition classes ( $N$-affected and $N$-unaffected) are shown in bold. Foliose lichens are lichens with basal thalli mainly flat on the ground like Cetraria ssp., Cladonia glauca or Cl. foliacea, Hypogymnea physodes and Peltigera ssp. Shrub lichens are Cladonia spp. with no substantial basal thalli and only upwards growing structures, for example, Cl. arbuscula, Cl. furcata, or Cl. uncialis.

conditions for a system shift to a vegetation dominated by Carex. Similar shifts in competitive relationships at increasing $\mathrm{N}$-levels have been reported from heathlands and coniferous forests (Aerts and others 1990; Berendse and Aerts 1984; Heil and Bruggink 1987; Keller and Redbo-Torstensson 1995). Another possible reason for grass encroachment is lack of (rabbit) grazing (Veer and Kooijman 1997), but rabbits have not been important grazers according to local site managers and nature conservationists within the 19 dune sites around the Baltic Sea during the last one to two decades, and no other herbivores like elk, red deer, roe deer or hare have been reported to have a major impact on these dry grassland dune systems. Thus, grazing can be excluded as an important factor for grass encroachment by Carex arenaria in Baltic dunes.

\section{Character of Carex-Dominated Vegetation Units}

Dominance by $C$. arenaria can vary considerably. Such vegetation units sometimes are species-rich and open (Harilaid or Pavilosta), but sometimes a species-poor, thick grass sward (Korshage or Gellen). The species-rich, more open Carex-dominated vegetation is a community known from Baltic dunes since the 1920s (Steffen 1931; Hueck 1932; Paul 1953). At the Curonian Spit, a slightly cal- careous and N-unaffected site today, Paul (1953) recorded during the late 1930s an average of 12 species in the optimal phase of a C. arenaria community (Cladonia spp. excluded). This number is still the same today, and, quite remarkably, species assemblages have not changed during the last seven decades. A decreased number of species (9) at slightly calcareous, $\mathrm{N}$-affected Baltic dunes is comparable to Dutch dunes (Veer and Kooijman 1997).

At higher $\mathrm{N}$ loadings, Carex dominance is characterized by a dense grass sward. With increasing biomass the light availability decreases, and a dense root network is established (Veer and Kooijman 1997). These types of Carex units are probably quite persistent. Once a thick grass sward is set up, it is difficult for other plants and even trees to germinate and establish. Most of the few species that are still occurring in this vegetation unit (three on average) are relics of former, more open stages.

\section{The Effects of N-Deposition on Species Richness}

In acid dune systems, even $\mathrm{N}$-loads below $8 \mathrm{~kg} \mathrm{~N}$ ha ${ }^{-1} \mathrm{y}^{-1}$ can have a negative impact, while slightly calcareous sites are still well enough buffered by the carbonate system (Scheffer and Schachtschabel 1998; Blum 2007), and thus no acidifying impact of 
Table 6. Multiple Regression Results of Species Groups with the Factors Lichen-N, Al/Ca-ratio and pH

\begin{tabular}{|c|c|c|c|c|c|c|}
\hline \multirow{2}{*}{$\begin{array}{l}\text { Species } \\
\text { group }\end{array}$} & \multicolumn{2}{|l|}{ First stage } & \multicolumn{2}{|l|}{ Second stage } & \multicolumn{2}{|l|}{ Third stage } \\
\hline & Sig. factor (slope) & $\begin{array}{l}R^{2} \\
P \text {-level }\end{array}$ & Sig. factor (slope) & $\begin{array}{l}R^{2} \\
P \text {-level }\end{array}$ & Sig. factor (slope) & $\begin{array}{l}R^{2} \\
P \text {-level }\end{array}$ \\
\hline \multicolumn{7}{|l|}{ Acid sites } \\
\hline Foliose lichens & ns & & $\begin{array}{l}\mathrm{Al} / \mathrm{Ca} \text {-ratio }(-) \\
\text { Interaction with } \mathrm{pH} \\
\text { Interaction with lichen-N }\end{array}$ & $0.4765^{*}$ & Lichen N (-) & $0.2809^{\#}$ \\
\hline All lichens & ns & & $\begin{array}{l}\mathrm{Al} / \mathrm{Ca} \text {-ratio }(-) \\
\text { Interaction with } \mathrm{pH} \\
\text { Interaction with lichen-N }\end{array}$ & $0.4138^{\#}$ & ns & \\
\hline Grass & ns & & ns & & Lichen $\mathrm{N}(-)$ & $0.5860 * * *$ \\
\hline Forbs & $\begin{array}{l}\text { Lichen-N (+) } \\
\mathrm{pH}(+) \\
\text { Interaction of both }\end{array}$ & $0.8907^{* * *}$ & ns & & ns & \\
\hline Total & ns & & $\mathrm{pH}(+)$ & $0.1952^{\#}$ & Lichen $N(-)$ & $0.3143^{\#}$ \\
\hline \multicolumn{7}{|c|}{ Slightly calcareous sites } \\
\hline Foliose lichens & ns & & ns & & $\begin{array}{l}\mathrm{Al} / \mathrm{Ca}-\text { ratio }(-) \\
\text { interaction with lichen-N }\end{array}$ & $0.2416^{\#}$ \\
\hline All lichens & ns & & $\mathrm{pH}(-)$ & $0.3708^{* * *}$ & ns & \\
\hline Moss & ns & & $\begin{array}{l}\text { lichen-N (-) } \\
\text { Al/Ca-ratio (-) }\end{array}$ & $0.3567^{*}$ & ns & \\
\hline Grass & ns & & $\mathrm{pH}(-)$ & $0.1784^{\#}$ & ns & \\
\hline Forbs & Al/Ca-ratio $(-)$ & $0.1722^{\#}$ & $\begin{array}{l}\text { lichen-N }(-) \\
\mathrm{Al} / \mathrm{Ca}(-) \\
\text { interaction of both } \\
\mathrm{pH}(-)\end{array}$ & $0.5313 * * *$ & ns & \\
\hline
\end{tabular}

Significant factors with algebraic sign of the slope, $R^{2}$ and $P$-level are given $\left({ }^{* *} P<0.0001,{ }^{*} P<0.01,{ }^{*} P<0.05\right.$, not significant ns) for the different succession stages at acid and slightly calcareous sites separately.

this moderate atmospheric $\mathrm{N}$-deposition is occurring. As the three factors soil $\mathrm{Al} / \mathrm{Ca}$-ratio, N-deposition and soil $\mathrm{pH}$ are strongly intercorrelated, their impact cannot be separated totally, but their importance can be ranked. Kleijn and others (2008) could not observe any systematic difference between $\mathrm{Al} / \mathrm{Ca}$-ratio at growth sites of common and rare species, but rare species occurred at a restricted $\mathrm{pH}$-range. In this study, $\mathrm{Al} / \mathrm{Ca}$-ratio and $\mathrm{N}$-deposition (measured as lichen $\mathrm{N}$ ), showed the largest impact on dry coastal dunes.

Foliose lichens, which have their thalli directly flat on the ground, disappear along with two to three forb and grass species. Cladonia glauca and Festuca polesica do not grow at all at N-affected sites. Also in other habitats, coverage and species richness of lichens and mosses decrease at higher atmospheric deposition (Boorman and Fuller 1982; Heil and Diemont 1983; Ketner-Oostra and Sykora 2004; Lee and Caporn 1998; Van Tooren and others 1990). At ambient or artificial total N-deposition of $10 \mathrm{~kg} \mathrm{~N} \mathrm{ha}^{-1} \mathrm{y}^{-1}$ total plant species diversity was reduced in American prairie grasslands (Clark and
Tilman 2008), Swedish deciduous forests (Falkengren-Grerup and Diekmann 2003) and British grasslands (Stevens and others 2004, 2006). Particular to Baltic dunes, there seems to be a decrease in foliose lichens even at moderate deposition loads of less than $8 \mathrm{~kg} \mathrm{~N} \mathrm{ha}^{-1} \mathrm{y}^{-1}$ wet deposition, whereas shrub-thalli lichens do not change their coverage under these conditions. At $\mathrm{N}$-affected field sites, soil pH is lower and $\mathrm{Al}$ and Fe are more available than under pristine conditions, and hence, lichen species not adapted to these high concentrations might take up more metals, which may affect their vitality (Hauk and others 2002, 2007).

\section{Recommendations for Coastal Dune Management}

Ecological thresholds and early indicators for ecosystem changes are well used tools in nature conservation and management, though research of their practical application to various ecosystems is still needed (Groffman and others 2006). This study 
elucidates the impact of low to medium loads of $\mathrm{N}$ deposition on coastal dunes. An early indicator for a dune system change due to N-loads of 5$8 \mathrm{~kg} \mathrm{~N} \mathrm{ha}^{-1} \mathrm{y}^{-1}$ may be an increased drop in soil $\mathrm{pH}$ between freshly deposited sand (parent material) and the first successional stage. If the total organic matter content (LOI) in the upper mineral soil horizon of lichen-rich, short grasslands (second stage) is above $1-1.5 \%$ and the $\mathrm{pH}$ is below $4.0-4.5$, the system is about to change. Heavy metals become freely available, for example, Al/Ca-ratios above 1 occur and short grasslands are no longer suitable for slow-growing lichen species. In particular Cladonia species growing with their thalli flat on the ground decrease their cover. Cladonia glauca and $\mathrm{Cl}$. macilenta agg. Hoffm. might be good indicator species of an intact system; higher coverages of Rumex acetosella or Dicranum scoparium in short grasslands indicate the opposite. Slightly calcareous sites are only marginally affected by these relatively low N-loads as the calcium buffer capacity is not completely depleted yet.

Stands of C. arenaria are a natural part of the Baltic coastal ecosystem (Steffen 1931; Hueck 1932; Paul 1953). If the coverage of C. arenaria per field site does not exceed 30-40\% (Remke and others 2009), these stands can be species rich (1216 species per $4 \mathrm{~m}^{2}$ plot). However, C. arenaria stands have become more widespread and more dense. At many sites, a dense, species poor (4-6 species per $4 \mathrm{~m}^{2}$ plot) grass sward has established over about $60-70 \%$ of the area (Remke and others 2009). Because soil conditions have been irrevocably altered, restoration of dune grasslands on such sites should include turf stripping, removal of soil enriched with organic matter (Ah-layer) and addition of low doses of lime (Dorland and others 2004; Symes and Day 2003).

\section{ACKNOWLEDGEMENTS}

This work was funded by the Ministry of Education, Science and Culture, Mecklenburg-Pommerania, Germany, and the Bargerveen Foundation, The Netherlands. We are grateful to numerous site managers, researchers and nature conservationists, who helped finding adequate field sites and getting research permits. Thanks also to Henriette Subklew for valuable assistance during field work and to Ankie De Vries-Brock, Jelle Eygenstein and Ulrich Möbius for support in the laboratory. We greatly acknowledge Cathy Jenks for checking the language and two anonymous reviewers and the editor for valuable comments.

\section{OPEN ACCESS}

This article is distributed under the terms of the Creative Commons Attribution Noncommercial License which permits any noncommercial use, distribution, and reproduction in any medium, provided the original author(s) and source are credited.

\section{REFERENCES}

Anonymous. 2004. State of environment 2004 report. Vilnius: Ministry of Environment of the Republic of Lithuania. http:// www.am.lt/VI/en/VI/article.php3?article_id=93.

Achermann B, Bobbink R. 2003. Empirical critical loads for nitrogen. Berne: SAEFL.

Aerts R, Berendse F, de Caluwe H, Schmitz M. 1990. Competition in heathland along an experimental gradient of nutrient availability. Oikos 57:310-18.

Aerts R, Bobbink R. 1999. The impact of atmospheric nitrogen deposition on vegetation processes in terrestrial, non-forest ecosystems. In: Langan SJ, Ed. The impact of nitrogen deposition on natural and semi-natural ecosystems. Dordrecht: Kluwer Academic Publishers. p 85-122.

Berendse F, Aerts R. 1984. Competition between Erica tetralix L. and Molinia caerulea (L.) Moench as affected by the availability of nutrients. Acta Oecol 5:3-14.

Biermann RW. 1999. Vegetationsökologische Untersuchungen der Corynephorus canescens-Vegetation der südlichen und östlichen Nordseeküste sowie der Kattegatinsel Læesø unter besonderer Berücksichtigung von Campylopus introflexus. Mitteilungen der Arbeitsgemeinschaft Geobotanik in Schleswig-Holstein und Hamburg.

Blum WEH. 2007. Bodenkunde in Stichworten, 6. völlig neu bearbeitete Auflage, Stuttgart: Gebr. Borntraeger.

Bobbink R, Heil GW, Raessen MB. 1992. Atmospheric deposition and canopy exchange processes in heathland ecosystems. Environ Pollut 75(1):29-37.

Bobbink R, Hornung M, Roelofs J. 1998. The effects of air-borne nitrogen pollutants on species diversity in natural and seminatural European vegetation. J Ecol 86(5):717-38.

Boorman LA, Fuller RM. 1982. Effects of added nutrients on dune swards grazed by rabbits. J Ecol 70:345-55.

Boorman LA, Van der Maarel E. 1997. Dune grasslands. In: Van der Maarel E, Ed. Dry coastal ecosystems. General aspects 2C. Amsterdam: Elsevier. p 323-44.

Clark CM, Tilman D. 2008. Loss of plant species after chronic low-level nitrogen deposition to prairie grasslands. Nature 451 (7179):712-15.

Crawley MJ. 2005. Statistics: An introduction using R. USA: Wiley.

Crawley MJ. 2007. The R Book. USA: Wiley.

De Graaf M, Bobbink R, Verbeek P, Roelofs J. 1997. Aluminium toxicity and tolerance in three heathland species. Water Air Soil Pollut 98(3-4):229-39.

D'Hertenfeld T, Falkengren-Grerup U. 2002. Extensive physiological integration of Carex arenaria and Carex disticha in relation to potassium and water availability. New Phytol 156: 469-77. 
D’Hertenfeld T, Jonsdottir IS. 1999. Extensive physiological integration in intact clonal systems of Carex arenaria. J Ecol $87: 258-64$.

Dorland E, van den Berg L, van de Berg A, Vermeer M, Roelofs J, Bobbink R. 2004. The effects of sod cutting and additional liming on potential net nitrification in heathland soils. Plant Soil 265(1-2):267-77.

Eggertsson-Karlström C. 2004. Väder och Vatten 13. Norrköpping: SMHI.

Ellenberg H. 1996. Vegetation Mitteleuropas mit den Alpen in ökologischer, dynamischer und historischer Sicht. Stuttgart: Ulmer.

Falkengren-Grerup U, Diekmann M. 2003. Use of a gradient of $\mathrm{N}$-deposition to calculate effect-related soil and vegetation measures in deciduous forests. For Ecol Manag 180(1-3):11324.

Feistel R, Nausch G, Wasmund N. 2008. State and evolution of the Baltic Sea, 1952-2005 A detailed 50-year survey of meteorology and climate, physics, chemistry, biology, and marine environment. USA: Wiley.

Fink A. 2007. Pflanzenernährung und Düngung in Stichworten, 6. völlig neu bearbeitete Auflage. Stuttgart: Gebr. Borntraeger.

Finnern H.1994. Ad-Hoc-Arbeitsgruppe Boden der Geologischen Landesämter und der Bundesanstalt für Geowissenschaften und Rohstoffe der Bundesrepublik Deutschland. Bodenkundliche Kartieranleitung. Mit 91 Tabellen. Stuttgart: Schweizerbart.

Frahm JP, Frey W. 1992. Moosflora. Stuttgart: Ulmer.

Grasshoff K, Johannsen H. 1977. A new sensitive method for the determination of ammonia in sea water. Water Res 2:516.

Groffman P, Baron J, Blett T, Gold A, Goodman I, Gunderson L, Levinson B, Palmer M, Paerl H, Peterson G, Poff N, Rejeski D, Reynolds J, Turner M, Weathers K, Wiens J. 2006. Ecological thresholds: the key to successful environmental management or an important concept with no practical application? Ecosystems 9(1):1-13.

Hauck M, Hesse V, Runge M. 2002. The significance of stemflow chemistry for epiphytic lichen diversity in a dieback-affected spruce forest on Mt Brocken, northern Germany. Lichenologist 34(5):415-27.

Hauck M, Huneck S, Elix JA, Paul A. 2007. Does secondary chemistry enable lichens to grow on iron-rich substrates? Flora 202(6):471-8.

Hegi G, Conert HJ, Eds. 1998. Illustrierte Flora von Mitteleuropa, 1-4. Berlin: Parey.

Heil G, Diemont W. 1983. Raised nutrient levels change heathland into grassland. Vegetatio 53(2):113-20.

Heij GJ, Schneider T, Eds. 1991. Acidification research in the Netherlands: final report of the Dutch priority programme on acidification. Amsterdam: Elsevier.

Heil GW, Bruggink M. 1987. Competition for nutrients between Calluna vulgaris (L.) Hull and Molinia caerulea (L.) Moench. Oecologia 73:105-7.

Heil GW, Werger MJA, De Mol D, Van Dam D, Heijne B. 1988. Capture of atmospheric ammonia by grassland canopies. Science 239:764-5.

Henriksen A. 1965. An automated method for determining lowlevel concentrations of phosphate in fresh and saline waters. Analyst 90:29-34.

Houdijk A, Smolders A, Roelofs J. 1993. The effects of atmospheric nitrogen deposition on the soil chemistry of coniferous forests in The Netherlands. Environ Pollut 80(1):73-8.
Hueck K. 1932. Erläuterung zur vegetationskundlichen Karte der Lebanehrung (Ostpommern). (Meßtischblatt Lebasee $171 \mathrm{z}$. T.). Neudamm, Neumann. Beiträge zur Naturdenkmalpflege.

Jensen A. 1986. Dry coastal ecosystems of Denmark. In: Van der Maarel E, Ed. Dry coastal ecosystems. 2A. Amsterdam: Elsevier. p 183-96.

Jones MLM, Wallace HL, Norris D, Brittain SA, Haria S, Jones RE, Rhind PM, Reynolds BR, Emmett BA. 2004. Changes in vegetation and soil characteristics in coastal sand dunes along a gradient of atmospheric nitrogen deposition. Plant Biol 6:598-605.

Keller O, Redbo-Torstensson P. 1995. Effects of elevated nitrogen deposition on the field layer vegetation in coniferous forests. Ecol Bull 44:227-37.

Ketner-Oostra R, Sykora KV. 2004. Decline of lichen diversity in calcium poor coastal dune vegetation since the 1970s, related to grass and moss encroachment. Phytocoenologica 35(4): 521-49.

Kingston HM, Haswell SJ. 1997. Microwave enhanced chemistry: fundamentals, sample preparation and applications. Washington, DC, USA: American Chemical Society.

Kleijn D, Bekker RM, Bobbink R, De Graaf MCC, Roelofs JGM. 2008. In search for key biogeochemical factors affecting plant species persistence in heathland and acidic grasslands: a comparison of common and rare species. J Appl Ecol 45(2):680-7.

Koerselman W, Meuleman A. 1996. The vegetation N:P ratio: a new tool to detect the nature of nutrient limitation. J Appl Ecol 33(6):1441-50.

Kooijman AM. 2004. Environmental problems and restoration measures in coastal dunes in The Netherlands. Chapter 15. Coastal dunes, ecology and conservation. In: Martinez ML, Psuty NP, Eds. Ecological studies, Vol. 171. Berlin: Springer. p 243-58.

Kooijman AM, Besse M. 2002. The higher availability of N and P in lime-poor than in lime-rich coastal dunes in the Netherlands. J Ecol 90(2):394-403.

Kooijman A, Dopheide J, Sevink J, Takken I, Verstraten J. 1998. Nutrient limitations and their implications on the effects of atmospheric deposition in coastal dunes; lime-poor and limerich sites in the Netherlands. J Ecol 86(3):511-26.

Kooijman AM, Kooijman-Schouten MM, Martinez-Hernandez GB. 2008. Alternative strategies to sustain $\mathrm{N}$-fertility in acid and calcaric beech forests: low microbial $\mathrm{N}$-demand versus high biological activity. Basic Appl Ecol 9(4):410-21.

Lautenschlager-Fleury D, Lautenschlager E. 1994. Die Weiden von Mittel- und Nordeuropa: Bestimmungsschlüssel und Artbeschreibungen für die Gattung Salix L. Basel: Birkhäuser.

Lajtha K, Schlesinger W. 1988. The biogeochemistry of phosphorus cycling and phosphorus availability along a desert soil chronosequence. Ecology 69(1):24-39.

Lee J, Caporn S. 1998. Ecological effects of atmospheric reactive nitrogen deposition on semi-natural terrestrial ecosystems. New Phytol 139(1):127-34.

Malloch AJC. 1997. Salt spray as a factor influencing dry coastal vegetation. In: Van der Maarel E, Ed. Dry coastal ecosystems. General aspects. Amsterdam: Elsevier. p 411-18.

Marschner H. 1995. Mineral nutrition of higher plants. London: Academic Press.

NEGTAP. 2001. Transboundary air pollution: acidification, eutrophication and ground-level ozone in the UK, National Expert Group on Transboundary Air Pollution, Edinburgh. http://www.maposda.net/negtap/finalreport.htm. 
Niedringhaus R, Haeseler V, Janiesch P, editors. 2008. Die Flora und Fauna der Ostfriesischen Inseln-Artenverzeichnisse und Auswertungen zur Biodiversität. Schriftenreihe Nationalparverwaltung Niedersächsisches Wattenmeer, 11.

Noble JC, Marshall C. 1983. The population biology of plants with clonal growth II. The nutrient strategy and modular physiology of Carex arenaria. J Ecol 71:865-77.

Oberdorfer E. 1994. Pflanzensoziologische Exkursionsflora. Stuttgart: Ulmer.

Olson DM, Dinerstein E, Wikramanayake ED, Burgess ND, Powell GVN, Underwood EC, D'Amico JA, Itoua I, Strand HE, Morrison JC, Loucks CJ, Allnutt TF, Ricketts TH, Kura Y, Lamoreux JF, Wettengel WW, Hedao P, Kassem KR. 2004. Terrestrial ecoregions of the world: a new map of life on earth. Bioscience 51:933-8.

Paul H. 1953. Morphologie und vegetation der kurischen Nehrung. II. Entwickllung der Pflanzendecke von der Besiedlung des Flugsandes bis zum Wald. Nova Acta Neopoldina N.F 16:261-378.

Power S, Ashmore M, Cousins D. 1998. Impacts and fate of experimentally enhanced nitrogen deposition on a British lowland heath. Environ Pollut 102(Suppl 1):27-34.

Provoost S, Bonte D (eds) (2004). Levende duinen: een overzicht van debiodiversiteit aan de Vlaamse kust. Mededelingen van het Instituut voor Natuurbehoud 22. Brussel.

Raab B, Vedin H, Eds. 1995. Sveriges Nationalatlas-klimat, sjöar och vattendrag. Höganäs: Bokförlaget Bra Böcker.

Ratas U, Nilson E., Eds. 1997. Small islands of Estonia. In: Landscape ecological studies issue 5. Tallinn: Institute of Ecology. 232 pp.

$\mathrm{R}$ development Core Team. 2008. R: A language and environment for statistical computing. R Foundation for Statistical Computing, Vienna, Austria. ISBN 3-900051-07-0. http:// www.R-project.org.

Remke E, Brouwer E, Kooijman AM, Blindow I, Esselink H, Roelofs JGM. 2009. Even low to medium nitrogen deposition impacts vegetation of dry, coastal dunes around the Baltic Sea. Environ Pollut 157(3):792-800.

Roelofs JGM. 1986. The effect of airborne sulfur and nitrogen deposition on aquatic and terrestrial heathland vegetation. Experientia 42(4):372-7.

Roelofs J, Kempers A, Houdijk A, Jansen J. 1985. The effect of air-borne ammoniumsulfate on Pinus nigra var. maritima in The Netherlands. Plant Soil 84(1):45-56.

Rothmaler W, Jäger EJ, Werner K. 2002. Exkursionsflora von Deutschland 3. Gefäßpflanzen: Atlasband and 4. Gefäßpflanzen: Kritischer Band, 9. völlig überarbeitete Auflage, Berlin; Heidelberg: Spektrum, Akadem. Verlag.

Scheffer F, Schachtschabel P. 1998. Lehrbuch der Bodenkunde. 14., neu bearb. und erw. Aufl., Stuttgart: Enke.

Søchting U. 1995. Lichens as monitors of nitrogen deposition. Cryptogamic Bot 5:264-9.

Steffen H. 1931. Vegetationskunde von Ostpreußen. Jena: Fischer.

Stevens CJ, Dise NB, Gowing DJG, Mountford JO. 2006. Loss of forb diversity in relation to nitrogen deposition in the UK: regional trends and potential controls. Global Change Biol $12(10): 1823-33$.
Stevens C, Dise N, Mountford J, Gowing D. 2004. Impact of nitrogen deposition on the species richness of grasslands. Science 303(5665):1876-9.

Stützer A. 1998. Early stages of podzolisation in young aeolian sediments, western Jutland. Catena 32(2):115-29.

Symes NC, Day J. 2003. A practical guide to the restoration and management of lowland heathland. Sandy, UK: RSPB.

Technicon. 1969. Industrial method 33-69 W, nitrate + nitrite in water. Technicon Autoanalyser Methodology. KarrytownNew York: Technicon Corporation. pp 1-2.

Tietema T. 1981. Ecophysiology of the sand sedge Carex arenaria L. Ph.D. thesis, University of Utrecht.

Troelstra S, Wagenaar R, Smant W, Peters B. 2001. Interpretation of bioassays in the study of interactions between soil organisms and plants: involvement of nutrient factors. New Phytol 150(3):697-706.

van den Berg LJL, Tomassen HBM, Roelofs JGM, Bobbink R. 2005. Effects of nitrogen enrichment on coastal dune grassland: a mesocosm study. Environ Pollut 138:77-85.

van Dijk HFG, Creemers RC, Rijniers JPLWM, Roelofs JGM. 1989. Impact of artificial ammonium-enriched rainwater on soils and young coniferous trees in a greenhouse. Part I- effects on the soil. Environ Pollut 62:317-36.

van Dijk HFG, De Louw MHJ, Roelofs JGM, Verburgh JJ. 1990. Impact of artificial ammonium-enriched rainwater on soils and young coniferous trees in a greenhouse. Part II-Effects on the trees. Environ Pollut 63:41-59.

Van Tooren BF, Odé B, During HJ, Bobbink R. 1990. Regeneration of species richness in the bryophyte layer of Dutch grasslands. Lindbergia 16:153-60.

Veer M, Kooijman AM. 1997. Effects of grass-encroachment on vegetation and soil in Dutch dry dune grasslands. Plant Soil 192(1):119-28.

Walna B, Polkowska Z, Małek S, Mędrzycka K, Namieśnik J, Siepak J. 2003. Tendencies of change in the chemistry of precipitation at three monitoring station 1996-1999. Polish J Environ Stud 12(4):467-72.

Wirth V. 1995. Flechtenflora. Bestimmung und ökologische Kennzeichnung der Flechten Südwestdeutschlands und angrenzender Gebiete. Stuttgart: Ulmer.

\section{URLS FOR CLIMATE DATA}

Greifswald-http://www.worldclimate.com/cgi-bin/grid.pl?gr= N54E013.

Duoedde-http://www.worldclimate.com/cgi-bin/grid.pl?gr=N5 5E015.

Kleipeda-http://www.worldclimate.com/cgi-bin/grid.pl?gr=N5 5E021.

Łeba-http://www.worldclimate.com/cgi-bin/grid.pl?gr=N54E017.

Liepaja-http://www.worldclimate.com/cgi-bin/grid.pl?gr=N56 E021.

Regions København and Nordsjælland-www.dmi.dk/dmi/index/danmark/vejrarkiv.htm. 